\title{
Canalicular adenoma of the upper lip: A case report
}

\author{
Marion Farias Guimarães ${ }^{a}$, Nikeila Chacon de Oliveira Conde ${ }^{a}$, Juliana Vianna Pereira ${ }^{a}$, \\ Max Eduardo Barroso de Amorimª ${ }^{\mathrm{a}}$, Suzana Cantanhede Orsini Machado de Sousa ${ }^{\mathrm{b}}$, \\ Tatiana Nayara Libório-Kimura ${ }^{\circ}$
}

\begin{abstract}
Objective: Canalicular adenoma is a relatively rare benign tumor of the salivary glands, found almost exclusively in the minor salivary glands of the upper lip. We report a case of canalicular adenoma in the upper labial mucosa of a male patient, highlighting the clinical and histopathological differential peculiarities compared to other lesions of similar location. The immunohistochemistry was considered decisive for diagnosis confirmation and differentiation from lesions that may have similar histological characteristics.

Case Description: A 68-year-old melanoderm male patient sought dental care for an asymptomatic lesion in the upper lip, measuring $7 \mathrm{~mm}$, with 1 year of evolution. Excisional biopsy, microscopic evaluation, and immunohistochemical assays were performed using antibodies against CK7, S-100, and vimentin antigens. The final diagnosis of canalicular adenoma was established through the consolidation of clinical, histological, and immunohistochemical data, taking into account the differential diagnosis of this lesion. After 1 year, the patient had no recurrences.

Conclusion: Immunohistochemistry was a definitive tool for the final diagnosis, ruling out the possibility of other lesions with similar morphology.
\end{abstract}

Key words: Adenoma; Diagnosis, differential; Salivary glands; Immunohistochemistry

\section{Adenoma canalicular em mucosa labial superior: relato de caso}

\section{Resumo}

Objetivo: O adenoma canalicular é um tumor benigno de glândulas salivares, relativamente raro, localizado quase exclusivamente nas glândulas salivares menores do lábio superior. Neste trabalho, foi relatado um caso clínico de adenoma canalicular em mucosa labial superior de paciente do sexo masculino, abordando peculiaridades clínicas e histopatológicas diferenciais com outras lesões de localização semelhante. Considerouse também a importância da imunoistoquímica para a confirmação diagnóstica e para a diferenciação com lesões que podem apresentar características histológicas semelhantes.

Descrição do caso: Paciente do sexo masculino, 68 anos de idade, melanoderma, procurou atendimento odontológico apresentando lesão assintomática no lábio superior, medindo $7 \mathrm{~mm}$, com 1 ano de evolução. Foi realizada biópsia excisional, avaliação microscópica e reações imunoistoquímicas utilizando anticorpos contra os antígenos CK7, S-100 e vimentina. O diagnóstico definitivo de adenoma canalicular foi estabelecido através da consolidação dos dados clínicos, histológicos e imunoistoquímicos e considerando-se os diagnósticos diferenciais com esta lesão. Após 1 ano, o paciente não apresentou recorrências.

Conclusão: A imunoistoquímica representou uma ferramenta importante para definição do diagnóstico final, descartando a possibilidade de outras lesões com morfologias semelhantes.

Palavras-chave: Adenoma; Diagnóstico diferencial; Glândulas salivares; Imuno-histoquímica
School of Dentistry, Federal University of Amazonas, Manaus-AM, Brazil

School of Dentistry, University of São Paulo, São Paulo-SP, Brazil

'School of Medicine, Federal University of

Amazonas, Manaus-AM, Brazil

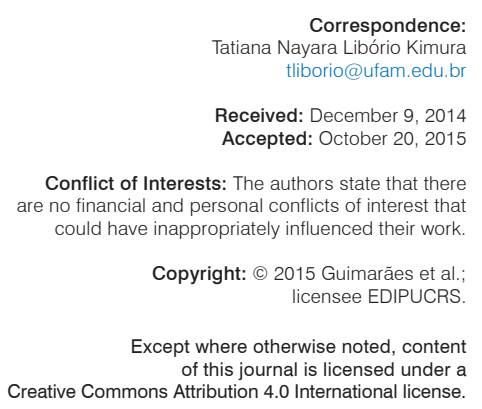




\section{Introduction}

Salivary gland tumors are relatively rare; the annual incidence of those tumors varies between 1.0 and 6.5 cases per 100,000 individuals worldwide, with the majority of tumors originating in the parotid gland $(64 \%$ to $80 \%)$, followed by the submandibular gland ( $8 \%$ to $11 \%$ ), and finally the minor salivary glands $(9 \%$ to $23 \%)[1,2]$.

Canalicular adenoma (CA) is a rare benign tumor of the minor salivary glands, originating in the excreting duct. Clinically, it is a small tumor located mainly in the upper lip, followed by the buccal mucosa and the palate, appearing as an asymptomatic movable submucosal nodule with slow growth. It occurs more often in adults over 60 years of age, with a slight trend towards women [2-4].

Microscopically, the CA is highly circumscriptive, consisting of a single layer of cuboid or columnar epithelial cells forming fine, interconnected cords that sometimes form canaliculi. In some areas it is possible to see adjacent parallel rows that look like a double layer or tumor cords. The loose conjunctive tissue stroma displays numerous blood vessels and some fibroblasts $[2,3]$.

Other lesions with similar characteristics to CA must be considered in the final diagnosis, including: trabecular basal cell adenoma (BCA), polymorphous low-grade adenocarcinoma (PLGA), adenoid cystic carcinoma (ACC), and ductal adenoma (DA) [5-8].

The preferred treatment consists of a conservative surgical excision, and recurrences are rare. Recurrence cases can be explained by the CA's multifocal nature. Bilateral tumors and several concomitant nodules in the upper lip have been reported in the literature $[3,4,7]$.

This case reports the event of a circumscriptive nodule in the upper lip mucosa of a male patient, 68 years of age, diagnosed as canalicular adenoma. The differential diagnosis included lesions that may display clinical and histopathological characteristics similar to this lesion. The diagnosis was established through the consolidation of clinical, histological, and immunohistochemical data.

\section{Case Description}

A 68-year-old melanoderm male patient, came to the Stomatology clinic at the Federal University of Amazonas, Manaus, AM, Brazil, complaining of a "swelling" in the mucosa of the upper lip. The lesion was asymptomatic and slow growing, and had been progressing for approximately one year. The patient's medical history revealed no systemic conditions. There appeared to be no facial asymmetry or lymphadenopathy. The intraoral examination detected a floating solid nodule with approximately $1 / 4 "(7 \mathrm{~mm})$ diameter with a smooth surface that moved when touched and was covered by a normal mucosa.

The patient underwent an excisional biopsy that revealed, during the surgery, the presence of a distinct nodule, apparently encapsulated, with a fibro elastic consistency, round shape, with approximately $1 / 4 "(7 \mathrm{~mm}$ ) diameter (Figure A and B).
The fragment was fixed in 10\% formaldehyde and sent to the Pathology and Forensic Medicine Laboratory of the School of Medicine at the Federal University of Amazonas for processing and microscopic analysis for a possible benign lesion of the minor salivary gland.

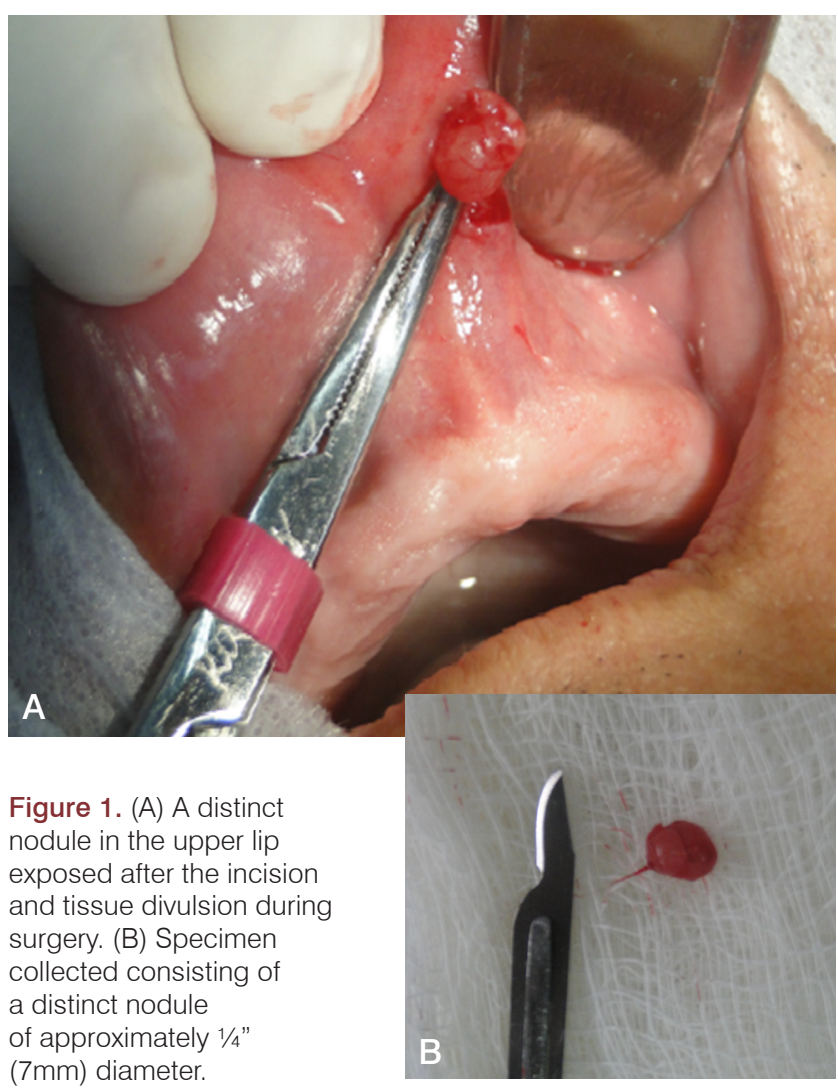

Microscopically, the histological sections stained with hematoxylin and eosin (HE) revealed a neoplastic segment of circumscriptive glandular origin, partially encapsulated, characterized by the formation of columnar cells with basophilic nuclei and loose chromatin. The neoplastic cells were arranged in cords that sometimes appeared to be adjacent to other similar formations, looking like 2-layer compositions around ductal structures. Acinar cells were also observed in small groups through the canalicular formations, with the stroma made of loose conjunctive tissue with hyalinized areas (Figure $2 \mathrm{~A}$ and B). According with these findings, the histopathological diagnosis was compatible with canicular adenoma.

In order to eliminate the possibility of other lesions of the salivary gland with similar morphology, the sample was submitted to immunohistochemical assays using antibodies against cytokeratin (CK)7, S-100, and vimentin antigens. The results were positive for anti-S-100 and anti-CK7 (Figure 3, $\mathrm{A}$ and $\mathrm{B}$ ) and negative for anti-vimentin. The consolidation of the clinical, histological, and immunohistochemical data confirmed the canicular adenoma diagnosis. One year after the surgery the patient does not show recurrence and is still under observation. 

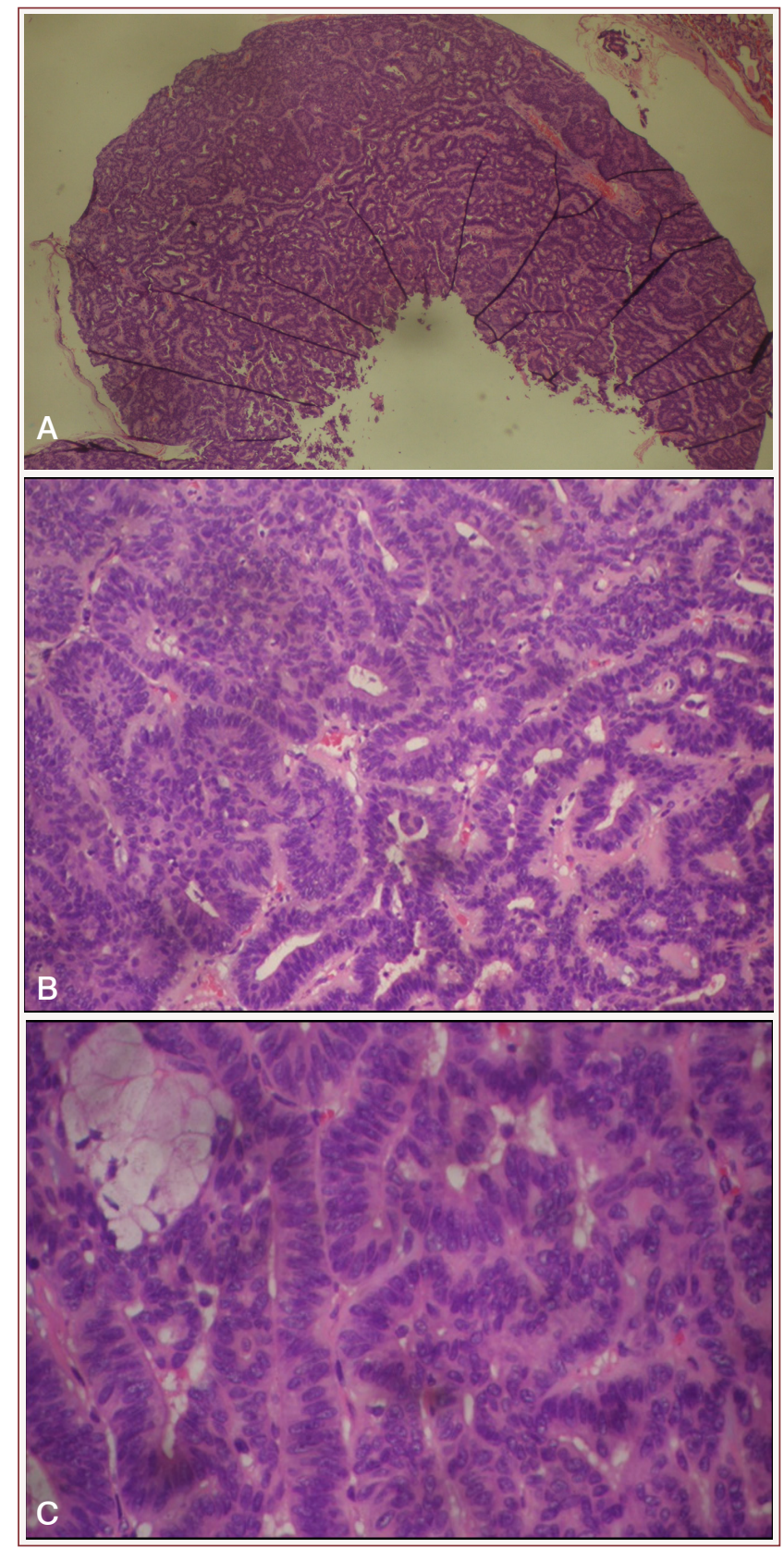

Figure 2. (A) Microscopic examination showing a benign partially encapsulated glandular neoplasm (H\&E, ×40). (B) Monotonic pattern of long ducts arranged in columnar epithelial cords with highly basophilic nuclei $(H \& E, \times 200)$. (C) Dense conjunctive tissue stroma, sometimes loose with vascularized areas and acinar cells area on the left $(H \& E, \times 400)$

\section{Discussion}

Canicular adenoma (CA) occurs more frequently in minor salivary glands, and approximately two thirds of all cases involve the upper lip, with most cases found in women and individuals over 60 years of age [3]. The patient is a 68 -year old male with a lesion in the upper lip mucosa. The anatomic site of the lesion and the patient's age group match the literature, but the gender is not the most common.
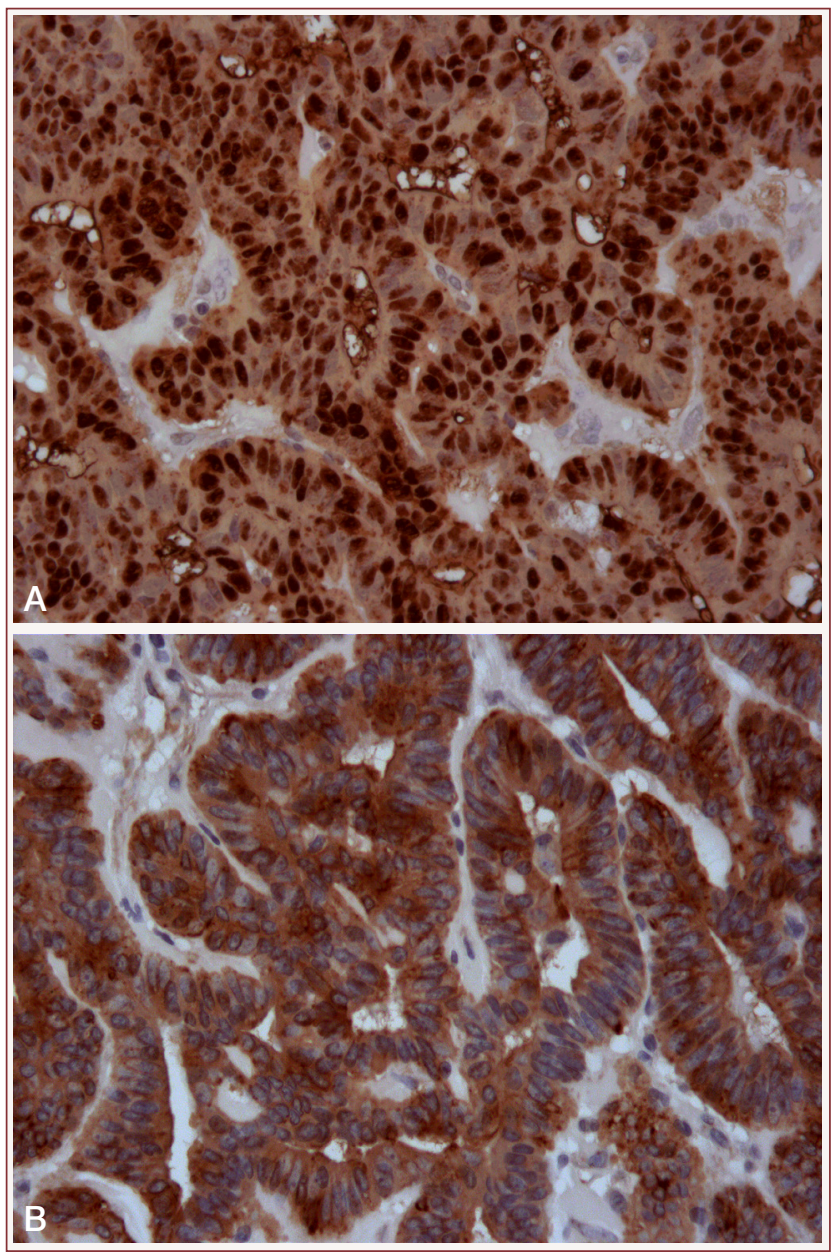

Figure 3. Positive immunoreactivity for anti-S-100 (A), identified by the staining in the cells nuclei, and for anti-CK7 (B), identified by the staining in the cells cytoplasm (Envision, DAB, $\times 400$ ).

The histopathological diagnosis of salivary gland tumors can be very challenging, especially when their morphology or structural arrangements are common to other lesions [9]. Traditionally, the CA is a well-encapsulated lesion with uniform morphology characterized by cords with a single layer of columnar or cuboidal epithelial cells arranged around ductal structures and supported by a loose vascularized conjunctive tissue stroma [2,4]. However, this lesion was partially encapsulated and contained spots of acinar cells, which required a more in-depth histological study of the lesion using immunohistochemistry to increase the precision and reliability of the case, since this histological aspect may mimic areas of other salivary gland lesions such as trabecular basal cell adenoma (BCA), ductal adenoma (DA), polymorphous low-grade adenocarcinoma (PLGA), and adenoid cystic carcinoma (ACC).

According to Oliveira-Santos et al. [3], the most important differential diagnosis for CA is malignant salivary gland tumors such as ACC and PLGA. Considering that a wrong malignity diagnosis might result in an incorrect CA approach, immunohistochemistry can be used to dismiss 
malignant lesions thus avoiding unnecessary aggressive therapies.

The basal cell adenoma (BCA) occurs typically in major salivary glands, especially in the parotid, however it can also occur in minor salivary glands of the upper lip as a second major possibility, which is also the most common site for CA $[2,10]$. Microscopically compared to CA, the $\mathrm{BCA}$ has a more collagenized stroma with fewer visible blood vessels. The BCA includes myoepithelial cells, while the CA consists exclusively of luminal cells [3]. Although uncommon, some BCA cases that are morphologically similar to CA can occur, especially the trabecular kind, which is histologically included in the differential diagnosis of this lesion $[3,7]$. Apparently, those cases exhibit characteristics of both segments of the glandular duct system - intercalated and excretory - and can account for the conflicting opinions found in the literature on the origin of those tumors [11]. In immunohistochemical assays, the BCA luminal cells reveal the presence of CK7, 8, and 14. The myoepithelial cells are positive for the vimentin antibody and, occasionally, with the specific muscle actin (SMA) and CK14 antibodies. CK13 is not present $[9,11]$.

Ductal adenoma (DA) is a benign salivary gland tumor, suggestively originating in the striate and excretory ducts, composed solely of ducts and a single layer of neoplastic epithelial cells, solid with minimum stroma. The ductal cells show prominent cell membranes (striates) that look like striated ducts. Unlike the intercalated ducts, DAs do not show the presence of a myoepithelial component morphologically. The causality discussed by Weinreb et al. [8] confirms this fact by the absence of a reaction to smooth muscle actin (SMA) in all six tumors as well as negativity for calponin and smooth muscle myosin heavy chain (SMMHC) in most tumors, except in two that showed focal positive immunoreactivity. DAs exhibit an immunoreactivity pattern for p63 similar to normal striated ducts, with a transition that ranges from negative to positive reaction in isolated cells or in groups of cells surrounding the ducts of some tumors. The striated duct system in this study also showed positive basal cells for CK5 and CK6 and myoepithelial cells positive for high molecular weight keratins (34BE12, CK14). The DA can be histologically confused with the CA, but detailed characteristics of its morphologic arrangement can differentiate them. While the latter tends to appear on the upper lip, most DA cases described in the literature are located in the parotid gland. The pattern of cells arranged in anastomosed cords, as well as the CA-typical abundant stroma are not present in the DA. CA cells exhibit basophilic cytoplasm and DAs have highly eosinophilic cytoplasms. As for the immunohistochemical profile, the CA is always negative for p63 and myoepithelial markers, and contain only ductal luminary cells. DAs contain isolated myoepithelial or basal cells despite consisting of a single layer of cells [8].

The cystic adenoid carcinoma is a malignant salivary gland neoplasm that exhibits slow growth and is common in the minor palate salivary glands, but can also appear in the upper lip in rare cases $[2,12]$. In addition to clinical characteristics common to CA, Palmeiro et al. report [12] that the ACC can also appear histologically with a predominance of cells in anastomosed cords or duct patterns, with areas that look like the CA cell arrangements, and is also included histologically in its differential diagnosis. The intercellular pseudo-cystic gaps, the invasive growth pattern, the perineural invasion, and the lack of a highly vascularized stroma present in ACC distinguish this malignant lesion from a CA [3]. Studies have shown the presence of CK7, 8 , and 14 in ACC luminal cells, and vimentin and musclespecific actin (MSA) in cells outside the lumen called myoepithelial cells [9]. Given ACC cases that look like $\mathrm{CA}$ with challenging differential diagnoses, the antibodies against those antigens can help to distinguish the lesions.

The canalicular adenoma and the PLGA are tumors that affect mostly the minor salivary glands. The CA occurs more often in the upper lip, while the PLGA tends toward the palate $[2,5]$. This may lead the pathologist to an incorrect diagnosis in PLGA cases located in the upper lip and consisting of a layer of columnar cells arranged in canals, which have the same histologic appearance as the CA $[5,13]$. Moreover, the partially encapsulated neoplasm morphology and the acinar cell groups seen in the lesion described in this case are more common in PLGA cases. In this case study, the lesion examined showed clinical characteristics typical of CAs described in the literature, suggesting a benign salivary gland lesion [3]. However, to confirm the diagnosis and to ensure a correct therapeutic approach, immunohistochemistry, which has been a safe tool widely used to discover the true nature of a lesion's tissue, was applied.

Several studies have used the antibody panel including vimentin, MSA, and cytokeratins (CKs), which have proved to be a useful tool to distinguish salivary gland tumors. In those studies, the immunohistochemical reactions in canalicular adenomas have shown that vimentin and MSA are not positive in tumor cells and all CKs expressed by normal cells of the excretory duct, CK7, CK8, CK13, CK14, and CK19 were positive $[5,9,11,14]$. Pereira et al. [6] and Oliveira-Santos et al. [3] reported cases of canalicular adenoma that were positive for the AE1/AE3 cytokeratin and for the S-100 protein. Corroborating with those authors, we used the antibody panel consisting of CK7, S-100, and vimentin.

According to Oliveira-Santos et al. [3], the CA immunohistochemical profile has been described in the literature including positivity for the AE1/AE3 cytokeratin, including CK7, and the S-100 protein, indicating its origin of the excretory duct luminal cells. For Araújo et al. [9], most CA cells are positive for CK13, thus showing its origin of the excretory duct luminal cells, and this marker reacts positively only in cases of canalicular adenoma and mucoepidermoid carcinoma. The strong and frequent staining for the S-100 protein is the main CA characteristic. That protein is a non-specific marker since it stains myoepithelial and luminal differentiation cells, and is useful for diagnostics support $[6,9]$. Vimentin has been identified in all tumors 
consisting of myoepithelial cells, suggesting that it is one of the first markers to differentiate neoplastic myoepithelial cells [14]. Despite the fact that the monotonous morphology, consisting of a layer of epithelial cells forming canals, has led to a canalicular adenoma diagnosis, it is known that the PLGA can present this same morphologic appearance. To eliminate the possibility of a PLGA lesion and - indirectly - other lesions such as $\mathrm{ACC}$ and $\mathrm{ACB}$, the negative result for vimentin in this immunohistochemical panel confirmed the CA diagnosis. Vimentin was important in this case because the PLGA cells are positive for this protein while most CA cells are negative [5]. The vimentin expression in PLGA occurs because this is a salivary gland tumor with myoepithelial differentiation. Its negative CA expression, based on the immunohistochemical panel used, suggests that this tumor consists only of cells of excretory duct origin.

Oliveira-Santos et al. [3] reported a canalicular adenoma case using the immunohistochemical panel consisting of CK AE1/AE3, S-100, p63, and Ki-67. P63 is a selective immunohistochemical marker for stratified epithelial basal cells and myoepithelial cells [15]. PLGA and most ACC cases show positive immunoreactivity for $\mathrm{p}-63$. CAs show negativity for p63 with the absence of myoepithelial differentiation consistent with the differentiation of luminal cells of the putative duct in this tumor. $\mathrm{Ki}-67$ is a nuclear antigen associated with cell proliferation, and its absence in CAs is compatible with a benign tumor [3]. The immunohistochemical panel for the CA differential diagnosis can also be used including p63 and Ki-67, whose absence can exclude the possibility of myoepithelial differential tumors and malignant tumors such as PLGA and ACC.

Based on this study, we concluded that the histologic aspects observed in the canalicular adenoma were similar to those described in the literature. However, other salivary gland lesions can mimic it histologically, and the immunohistochemical assay is critical to the final diagnosis. The immunoreactivity result of the antibody panel used corroborated the histopathological reading, especially with the absence of expression of the protein related to the myoepithelial differentiation, represented by vimentin.

\section{References}

1. Pires FR, Pringle GA, Almeida OP, Chen S. Intraoral minor salivary gland tumors: a clinicopathological study of 546 cases. Oral Oncol 2007;43: 463-70.

2. Neville BW, Damm DD, Allem CM, Bouquot JE, Chi AC, Gonzales TS et al Patologia Oral e Maxilofacial. Trad. 3aㅡ ed. Rio de Janeiro: Elsevier; 2009.

3. Oliveira-Santos C; Freitas-Faria P; Damante $\mathrm{JH}$; Consolaro A. Asymptomatic nodules of the upper lip: report of a canalicular adenoma with immunoprofile presentation. The Gerodontology Society and John Wiley \& Sons A/S, Gerodontology 2012;29:e1121-e1124.

4. Queiroz LMG, Silveira EJD, Arruda MLS, Ramos CCF. A rare salivary gland neoplasm: multiple canalicular adenoma. A case report. Auris Nasus Larynx 2004;31:189-93.

5. Furuse C, Tucci R, Sousa SOM, Carvalho YR, Araújo VC. Comparative Immunoprofile of Polymorphous Low-Grade Adenocarcinoma and Canalicular Adenoma. Ann Diagn Pathol 2003;7(5):278-80

6. Pereira MC; Pereira AAC; Hanemann JAC. Immunohistochemical profile of canalicular adenoma of the upper lip: a case report. Med Oral Patol Oral Cir Bucal 2007;12:E1-3

7. Yoon AJ, Beller DE, Woo VL, Pulse CL, Park A, Zegarelli DJ. Bilateral canalicular adenomas of the upper lip. Oral Surg Oral Med Oral Pathol Oral Radiol Endod 2006;102(3):341-3.

8. Weinreb I, Simpson RH, Skálová A, Perez-Ordoñez B, Dardick I, Chetty $\mathrm{R}$, et al. Ductal adenomas of salivary gland showing features of striated duct differentiation ('striated duct adenoma'): a report of six cases. Histopathology 2010;57:707-15.

9. Araújo VC, Sousa SOM, Carvalho YR, Araújo NS. Application of immunohistochemistry to the diagnosis of salivary gland tumors. Applied immunohistochemistry \& Molecular Morphology 2000;8(3): 195-202

10. Yong Huang. Basal cell adenoma in the parotid: a bizarre myoepithelialderived stroma rich variant. Int J Clin Exp Pathol 2014;7(7):4512-5

11. Sousa SOM, Araújo NS, Corrêa L, Soubhia AMP, Araújo VC. Immunohistochemical aspects of basal cell adenoma and canalicular adenoma of salivary glands. Oral Oncology 2001;37:365-8.

12. Palmeiro MR, Figueiredo MAS, Cherubini K, Yurgel LS. Carcinoma Adenóide Cístico - relato de caso. Rev Odonto Ciênc 2005;20(50):388-92.

13. Araújo VC, Passador-Santos F, Turssi C, Soares AB, Araujo NS Polymorphous low-grade adenocarcinoma: an analysis of epidemiological studies and hints for pathologists. Diagnostic Patholog 2013;8(6):1-8.

14. Vasconcellos LMR, Silveira VAS, Rosa LEB, Cavalcante ASR, Carvalho YR. Immunohistochemistry as a fundamental tool for the differential diagnosis of polymorphous low-grade adenocarcinoma. Quintessence Int 2006;37(7):565-73.

15. Edwards PC; Bhuiya T; Kelsch RD. Assessment of p63 expression in the salivary gland neoplasms adenoid cystic carcinoma, polymorphous lowgrade adenocarcinoma, and basal cell and canalicular adenomas. Oral Surg Oral Med Oral Pathol Oral Radiol Endod 2004;97(5):613-9. 